\title{
Review: Fossil Hunting in East Africa
}

Source: The Geographical Journal, Vol. 42, No. 4 (Oct., 1913), pp. 389-390

Published by: geographicalj

Stable URL: http://www.jstor.org/stable/1779073

Accessed: 29-03-2016 16:06 UTC

\section{Your use of the JSTOR archive indicates your acceptance of the Terms \& Conditions of Use, available at}

http://about.jstor.org/terms

JSTOR is a not-for-profit service that helps scholars, researchers, and students discover, use, and build upon a wide range of content in a trusted digital archive. We use information technology and tools to increase productivity and facilitate new forms of scholarship. For more information about JSTOR, please contact support@jstor.org.

The Royal Geographical Society (with the Institute of British Geographers), Wiley are collaborating with JSTOR to digitize, preserve and extend access to The Geographical Journal 
Nubian, and its name Don is even connected with Dongola. The account given of these people makes it reasonably certain that they are Nubas from southern Kordofan, and not Nubians from the Nile valley north of Khartum. Further, the Jebel Dyre of Bruce should not be identified with Jebel Eliri in southern Kordofan (liv.), and it is difficult to see why the author should have avoided the commonly accepted view that Bruce's Dyre is Jebel Daier in northern Kordofan.

These criticisms having been made, there remains nothing but unqualified praise for the book. A large amount of valuable ethnographical information will be founnd in the texts and stories which make up nearly half the book, though this, it must be remembered, is written by a philologist, not by an ethnologist. In a chapter on phonetics Prof. Westermann shows how important is the part played by tone in the Shilluk language, and he distinguishes a middle as well as a high and low tone, the former being the least easily recognized. The Shilluk language belongs to the clearly circumscribed group of African languages styled "Nilotic," which probably have arisen from the "Sudan" group, extending across the continent from Abyssinia to the Kamerun and northwards to Senegambia. Shilluk and the other Nilotic languages differ from these especially in having grammatical gender and many formative elements. Five criteria of the Nilotic languages are given, and they are grouped in two main subdivisions, viz.-

(a) The Niloto-Sudanic group, and

(b) The Niloto-Hamitic group.

Although there is no sharply defined boundary between these divisions, since they both contain elements of "Sudan" and Hamitic origin, they can be distinguished in practice by their resemblance to the Sudan and Hamitic languages respectively.

To the Niloto-Sudanic group belong Shilluk with its dialects, about a dozen in number, Dinka and Nuer, while a number of tribes, the Mittu, Madi, Abokaya, Abaka, Luba, Wira, Lendu, and Moru, seem to form a subdivision of the Niloto-Sudanic group, although their vocabularies vary considerably from those of the Shilluk and Dinka languages. The importance of this conclusion from the ethnological standpoint is very great, since it affords positive evidence of the existence of Hamitic influence among the comparatively short, mesaticephalic population of the watershed between the Bahr-el-Ghazal and Congo, sufficiently intense to so modify their languages that they can no longer be classified with the parent "Sudan" linguistic stock.

C. G. S.

\section{Fossil Hunting in East Africa.}

'Am Tendaguru. Leben und Wirken einer deutschen Forschungsexpedition zur Ausgrabung vorweltlicher Riesensaurier in Deutsch-Ostafrika.' Von Dr. Edw. Hennig. Mit 62 Abbildungen im Text, 8 schwarzen, 1 farbigen Tafel und 1 Kartenskizze. Stuttgart: E. Schweizerbart'sche Verlagsbuchhandlung. 1912. Pp. 151. Price M.4; bound, M.4.80.

Dr. Hennig went out with Prof. W. Branca to dig out remains of extinct saurians on the Tendaguru hill, near the right bank of the Mbenkuru river in German East Africa. The remains were first discovered by an engineer, Herr B. Sattler, and Prof. Fraas, who was then in the country, obtained some valuable material, and the expedition of Prof. Branca went out to complete the work. The bones of the Dinosaurians were found mingled with small bones of a softer material, which might belong to fossil birds or flying lizards: 
wood of land-plants, and remains of animals which undoubtedly lived in water. They must, therefore, have been carried hither and thither in water until finally deposited where they were found. They occur at three different levels, and the shells present with them will probably give a clue to their geological age. The saurians surpass in dimensions those discovered in America. The humerus of the plaster cast of an American Diplodocus in the Berlin Museum measures 0.95 metre (37 $\frac{1}{2}$ inches), whereas the largest found on the Tendaguru is more than $82 \frac{1}{2}$ inches long. The length of the neck of the Berlin Diplodocus is about 23 feet, that of the Tendaguru more than 39. The rump and tail vertebræ, however, correspond in size to the American, so that the Tendaguru animal cannot have been nearly double as long, as the proportions of the other bones would imply.

Dr. Hennig has also written chapters on the existing fauna and flora, the inhabitants, their habits and mode of life, etc.

'In the Heart of Savagedom.' By Mrs. Stuart Watt. (London: Marshall Bros. [Not dated; 1913.] Illustrations. Pp. 472. Price 7s. 6 $d$. net.) A record of over twenty-five years' heroic missionary labour in Central Africa. The author and her husband (who edits the work) went out, apparently at their own expense, in 1885, and began work at Mamboia, in the Ugogo region of German East Africa, where they remained some years, but eventually abandoned the station owing to failure in health. 'They returned to the mission field, however, and, after an attempt to found a station among the Wa-kikuyu, fixed on Akamba as their field of operations. The natives at first made attempts to plunder and murder them; but gradually a better understanding was arrived at, and a flourishing mission, self-supporting through its fruit plantations and other activities, built up. The author narrates her experiences in a plain, yct readable manner; and though her views may not meet with universal acceptance, yet the simple sincerity of the narrative and quiet courage displayed throughout make their own appeal. The illustrations are mostly good, but there is no index.

'In French Africa.' By M. Betham-Edwards. (London: Chapman \& Hall. 1912. Pp. x., 324. Illustrations. 10s. 6d.) The title of this volume leaves something to the imagination; the book is concerned actually with Algeria. It contains a readable narrative and impressions of a number of well-known places in that territory, and of some which visitors there seldom reach.

'The Adventures of an Elephant Hunter.' By James Sutherland. (London: Macmillan. 1912. Pp. xviii., 324. Illustrations. 7s. 6d.) The title describes the greater part of the text exactly, and sufficiently stirring. some of the adventures are. We find incidentally some notes as to native customs and the like, from the hunter's special point of view, and a useful appendix refers to water-bearing plants, edible fruits, plants serving other purposes, etc.

\section{AMERICA.}

'Labrador. The Country and the People.' By W. T. Grenfell, c.M.G., M.D., and others. New Edition. (New York: The Macmillan Co. 1913. Fp. xii., 529. Map and Illustrations. 10s. 6d. net.) Dr. Grenfell has brought out a new edition of his excellent and comprehensive work on Labrador (see Geographical Journal, vol. 36, p. 725). A useful bibliography has been added, and a new chapter on the natural history of the land mammals, and the author briefly discusses the future of Labrador. With a decrease in almost all the land and sea animals, the prospects are none too bright, but Dr. Grenfell refuses to think 